\title{
Studies on Formation and Decomposition of the Layered Cobaltite $\mathrm{Li}_{x} \mathrm{Na}_{y} \mathrm{CoO}_{2}$
}

\author{
A. S. Semenova, ${ }^{1}$ R. F. Samigullina, ${ }^{1}$ E. V. Shalaeva, ${ }^{1}$ N. I. Kourov, ${ }^{2}$ and D. G. Kellerman ${ }^{1,3}$ \\ ${ }^{1}$ Institute of Solid State Chemistry, Ural Branch of the Russian Academy of Science, 620990 Ekaterinburg, Russia \\ ${ }^{2}$ Institute of Metal Physics, Ural Branch of the Russian Academy of Science, 620041 Ekaterinburg, Russia \\ ${ }^{3}$ Department of Analitical Chemistry, Institute of Natural Sciences, Ural Federal University named after the First Russian President \\ B. N. Yeltsin, 620002 Ekaterinburg, Russia
}

Correspondence should be addressed to A. S. Semenova, semenova@ihim.uran.ru

Received 23 June 2011; Accepted 6 December 2011

Academic Editor: Rabindranath Mukherjee

Copyright ( 2011 A. S. Semenova et al. This is an open access article distributed under the Creative Commons Attribution License, which permits unrestricted use, distribution, and reproduction in any medium, provided the original work is properly cited.

\begin{abstract}
Lithium-sodium cobaltite $\mathrm{Li}_{x} \mathrm{Na}_{y} \mathrm{CoO}_{2}(x \approx y \approx 0.5)$ with ordered layered structure is promising thermoelectric material. Here we report the peculiarities of this phase formation and decomposition processes studied by TG/DTA, XRD, SEM, and TEM methods. Significant weight loss resulting from oxygen liberation and endothermic effect at $T \approx 1000^{\circ} \mathrm{C}$ are the main features of the $\mathrm{Li}_{x} \mathrm{Na}_{y} \mathrm{CoO}_{2}$ formation. Decomposition of the ordered phase is accompanied by exothermic effect at $\approx 940^{\circ} \mathrm{C}$ and the weight increase. Electron microscopic study shows that the lithium-sodium cobaltite decomposes into $\mathrm{LiCoO}_{2}$ and $\gamma-\mathrm{Na}_{0.7} \mathrm{CoO}_{2}$. Lattices of the initial phase and formed ones demonstrate mutual orientation.
\end{abstract}

\section{Introduction}

Over the last twenty years, layered metal oxides with the general formula $\mathrm{AMeO}_{2}$ (A-alkaline and Me-transition metal) have been the most extensively studied materials since the properties they possess make them attractive electrode materials for chemical power sources $[1,2]$. Special attention is being paid to the lithium cobaltite $\mathrm{LiCoO}_{2}$ as a material used in commercial Li-ion batteries. However, the interest in the $\mathrm{Li}_{1-x} \mathrm{CoO}_{2}$ system is due not only to its practical importance but also to the dramatic changes in structural, electronic, and magnetic properties occurring as a result of Li deintercalation/intercalations [3-9].

Regardless of the lithium content, the lithium cobaltites $\mathrm{Li}_{1-x} \mathrm{CoO}_{2}$ have a hexagonal structure with $\mathrm{Li}-\mathrm{O}-\mathrm{Co}-\mathrm{O}-$ $\mathrm{Li}-\mathrm{O}$. . layers stacked in the $\mathrm{ABCABC}$ sequence with an octahedral coordination of alkaline and transition elements $[10,11]$. A different situation is observed for $\mathrm{Na}_{x} \mathrm{CoO}_{2}$. There are phases, whose structures depend not only on the content of the alkaline element but also on the preparation conditions $[12,13]$. Similarly to the lithium cobaltite, the structures of the $\mathrm{Na}_{x} \mathrm{CoO}_{2}$ phases consist of alkaline ion triangular planes positioned between edge-sharing $\mathrm{CoO}_{6}$ octahedra layers. However, the coordination of sodium ions can be either octahedral or prismatic depending on the three- or two-layer packing $[14,15]$. A great interest in the $\mathrm{Na}_{x} \mathrm{CoO}_{2}$ phases was stimulated by the discovery of superconductivity in the two-layer $\mathrm{Na}_{0.3} \mathrm{CoO}_{2}$ intercalated with water [16]. Moreover, the $\mathrm{Na}_{x} \mathrm{CoO}_{2}$ system was found to show a variety of intriguing phenomena [17-21].

By analogy with the lithium cobaltite, $\mathrm{Na}_{x} \mathrm{CoO}_{2}$ was initially proposed as a promising cathode material [22]. However, after it was shown that this compound (specified at first as $\mathrm{NaCO}_{2} \mathrm{O}_{4}$ ) exhibits simultaneously high thermoelectric power and low resistivity $(\mathrm{S} \approx 100 \mu \mathrm{V} / \mathrm{K}$ and $\rho \approx$ $200 \mu \Omega \mathrm{cm}$ at $300 \mathrm{~K}$ ) [23], the phases of the $\mathrm{Na}-\mathrm{Co}-\mathrm{O}$ system were considered as potential thermoelectrics [24-26].

The results of sodium and lithium cobaltites studies give us grounds to expect that the phase containing both alkaline metals simultaneously should demonstrate unique physical and functional properties. However, no solid solutions were found to exist in the $\mathrm{LiCoO}_{2}-\mathrm{Na}_{x} \mathrm{CoO}_{2}$ system [27]. At the same time, an ordered phase with a layered structure $\left(\mathrm{Li}_{0.43} \mathrm{Na}_{0.36} \mathrm{CoO}_{1.96}\right)$ was reported [28] to form in the region 
close to the equiatomic alkaline ions concentration. The structure of this phase was attributed to the $P 6_{3} m c$ space group with hexagonal lattice parameters $a=2.839(4)$ and $c=20.36(3) \AA$ and the ABCAACBA packing of oxygen layers. It is essential that lithium and sodium ions are not mixed but occupy separate planes between $\mathrm{CoO}_{2}$ layers. Here, Li ions have an octahedral environment, while sodium ions are in the trigonal prisms [28]. This ordered phase is a good thermoelectric material indeed [29]. In addition, effects of magnetic ordering were observed [30] at $T<100 \mathrm{~K}$. However, despite the promising properties of the ordered lithium-sodium cobaltite, there are only few works [27-33] devoted to this phase. The reason is that the double cobaltite is difficult to synthesize because it is thermodynamically stable only at $T>1000^{\circ} \mathrm{C}$ [28]. The purpose of the present work is to study the peculiarities of formation and decomposition of the ordered lithiumsodium cobaltite " $\mathrm{Li}_{0.5} \mathrm{Na}_{0.5} \mathrm{CoO}_{2}$." This information should be useful to ascertain the temperature range appropriative for " $\mathrm{Li}_{0.5} \mathrm{Na}_{0.5} \mathrm{CoO}_{2}$ " practical applications. On the other hand the ordered structure of the " $\mathrm{Li}_{0.5} \mathrm{Na}_{0.5} \mathrm{CoO}_{2}$ " can be considered as an example of long-period superlattice usually more typical for alloys than for oxides. Peculiarities of such phase decomposition are also of interest.

\section{Synthesis of Materials and Experimental Methods}

The mixed lithium-sodium cobaltite " $\mathrm{Li}_{0.5} \mathrm{Na}_{0.5} \mathrm{CoO}_{2}$ " was prepared by a solid-state reaction from a mixture of $\mathrm{LiCoO}_{2}$ and $\gamma-\mathrm{Na}_{0.7} \mathrm{CoO}_{2}(1: 1)$ synthesized in advance as described previously [34]. The unit-cell parameters were $a=2.817(2) \AA, c=14.052(3) \AA$ and $a=2.821(1) \AA, c=$ 10.92(3) $\AA$ for $\mathrm{LiCoO}_{2}$ and $\mathrm{Na}_{0.7} \mathrm{CoO}_{2}$, respectively.

$\mathrm{X}$-ray diffraction experiments were carried out using a SHIMADZU diffractometer MAXima_X XRD-7000. XRD patterns were analyzed with the JCPDS-ICDD database (ICDD, USA, Release 2004), and the lattice parameters were obtained using the WinXpow program. The composition of the mixed lithium-sodium cobaltite was determined by inductively coupled plasma atomic-emission spectrometry ICP-AES measurements (ICAP 6500, Thermo Fisher).

Thermal analysis measurements were carried out with a simultaneous TG-DTA apparatus-SETARAM SETSYS Evolution 1750 both in static air and in dynamic oxygen at the flow rate of $20 \mathrm{~mL} / \mathrm{min}$.

The thermopower and electrical resistivity data were collected with system for measuring of the electric properties on base Solartron 7081 Precision Voltmeter (Yokogawa 7651 Programmable DC Source). The experiments were carried out in temperature range 60-300 K.

Transmission electron microscopy was performed in diffraction and imaging modes on a JEM-200CX operating at a voltage of $160 \mathrm{keV}$. The microdiffraction patterns were obtained from regions of $\sim 200-500 \mathrm{~nm}$ in size. The samples suitable for the electron diffraction analysis were prepared through ultrasonic dispersion in ethanol for $5 \mathrm{~min}$ of powders precrushed in a mortar. A few droplets of the ethanol suspension were deposited on a holey carbon $\mathrm{Cu}$ grid.

The morphology of the samples was observed on a JEOL JSM-6390 LA scanning electron microscope (SEM).

\section{Results and Discussion}

3.1. The Study of the Ordered Cobaltite " $\mathrm{Li}_{0.5} \mathrm{Na}_{0.5} \mathrm{CoO}_{2}$ " Formation. There are essentially two ways to prepare the ordered mixed layered cobaltite " $\mathrm{Li}_{0.5} \mathrm{Na}_{0.5} \mathrm{CoO}_{2}$ ": from presynthesized $\mathrm{LiCoO}_{2}$ and $\mathrm{Na}_{x} \mathrm{CoO}_{2}$ and from a $\mathrm{Co}_{3} \mathrm{O}_{4}$, $\mathrm{Na}_{2} \mathrm{CO}_{3}$, and $\mathrm{Li}_{2} \mathrm{CO}_{3}$ powder mixture. According to previous works, it is not easy to obtain a pure phase no matter which method is employed. Most often $\mathrm{LiCoO}_{2}$ is found as an impurity in the final product [30]. In order to evaluate possible sources of discrepancy between the chemical compositions of the final product and the raw mixture, we examined the following processes: formation of $\mathrm{Na}_{x} \mathrm{CoO}_{2}$, formation of $\mathrm{LiCoO}_{2}$, and preparation of the mixed cobaltite $\mathrm{Li}_{0.5} \mathrm{Na}_{0.5} \mathrm{CoO}_{2}$ from carbonates and $\mathrm{Co}_{3} \mathrm{O}_{4}$ and from presynthesized $\mathrm{LiCoO}_{2}$ and $\mathrm{Na}_{x} \mathrm{CoO}_{2}$.

3.1.1. Formation of $\mathrm{Na}_{x} \mathrm{CoO}_{2}$ from a Mixture of $\mathrm{Co}_{3} \mathrm{O}_{4}$ and $\mathrm{Na}_{2} \mathrm{CO}_{3}$. Let us consider processes occurring during the interaction of the $\mathrm{Co}_{3} \mathrm{O}_{4}$ oxide and the sodium carbonate $\mathrm{Na}_{2} \mathrm{CO}_{3}$ taken in the ratio required for the obtaining of the hexagonal cobaltite $\gamma-\mathrm{Na}_{0.7} \mathrm{CoO}_{2}$ (Sp. gr. P6 $\left.6_{3} / m m c\right)$ [12]. As follows from the thermal analysis data (Figure 1(a)), both the decomposition of the sodium carbonate $\mathrm{Na}_{2} \mathrm{CO}_{3}(1)$ and the formation of the $\mathrm{Na}_{x} \mathrm{CoO}_{2}$ cobaltite (2) start at $\mathrm{T}>620^{\circ} \mathrm{C}$ and are accompanied by mass changes:

$$
\begin{gathered}
\mathrm{Na}_{2} \mathrm{CO}_{3} \longrightarrow \mathrm{Na}_{2} \mathrm{O}+\mathrm{CO}_{2} \uparrow \\
0.350 \mathrm{Na}_{2} \mathrm{CO}_{3}+0.333 \mathrm{Co}_{3} \mathrm{O}_{4}+0.326 \mathrm{O}_{2} \\
\longrightarrow \mathrm{Na}_{0.7} \mathrm{CoO}_{2}+0.350 \mathrm{CO}_{2} \uparrow .
\end{gathered}
$$

Melting of the undecomposed part of the sodium carbonate intensifies reaction (2), which is evident from a more abrupt way of the TG curve. The endothermic effect at $860^{\circ} \mathrm{C}$ is indicative of the melting. If reaction (2) is not completed, unreacted residues of the cobalt oxide can decompose (3):

$$
\frac{1}{3} \mathrm{Co}_{3} \mathrm{O}_{4} \longrightarrow \mathrm{CoO}+0.125 \mathrm{O}_{2} \uparrow \text {. }
$$

The endothermic effect observed at $911^{\circ} \mathrm{C}$ corresponds to this process.

Both DTG and DTA curves reveal peaks at $1020^{\circ} \mathrm{C}$, which can be ascribed to melting and evaporation of the formed sodium cobaltite. $\mathrm{Na}_{0.7} \mathrm{CoO}_{2}$ was found [35] to melt incongruently. Due to the decomposition of the cobalt oxide (3) and evaporation of molten sodium cobaltite, the total weight loss is almost 20\% higher than that resulting from reaction (2). The possibility of these processes must be taken into account in synthesis of the mixed lithium-sodium cobaltite " $\mathrm{Li}_{0.5} \mathrm{Na}_{0.5} \mathrm{CoO}_{2}$." 


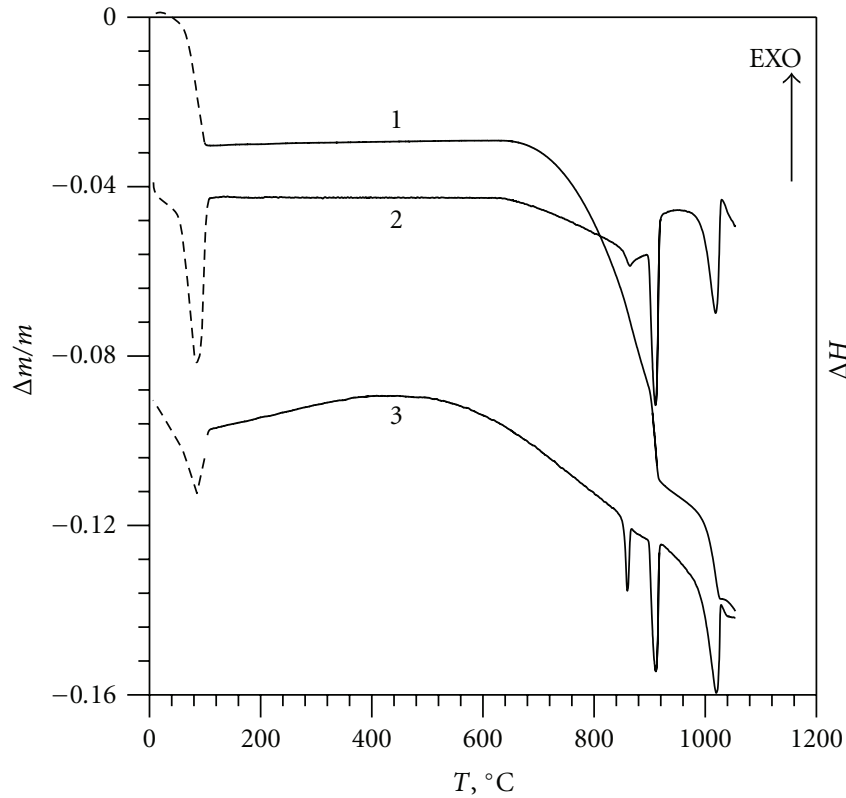

(a)

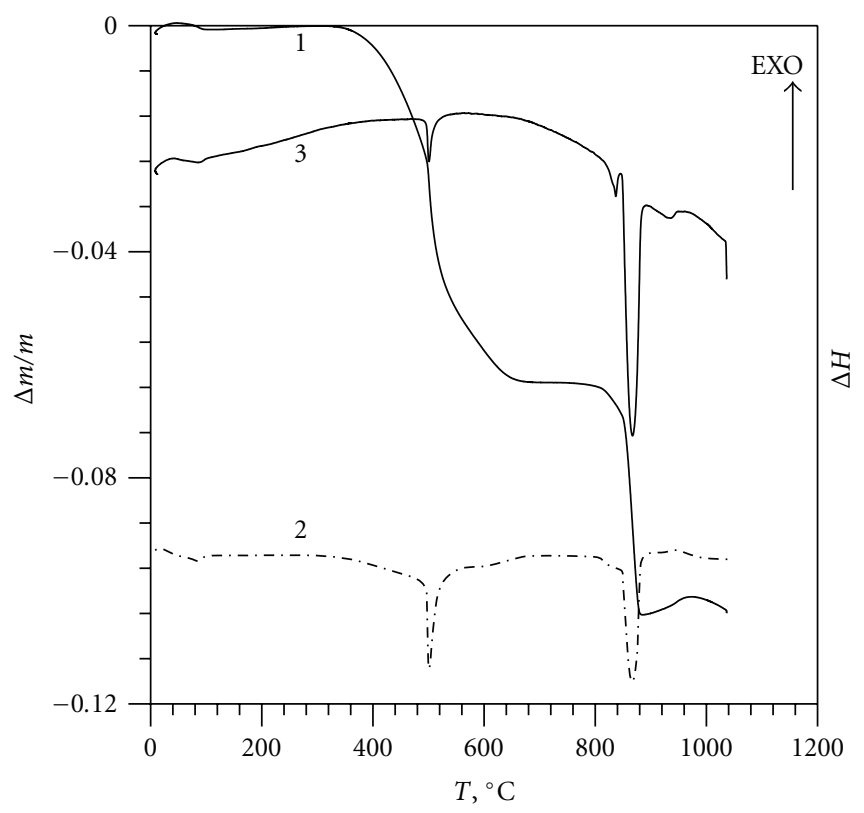

(c)

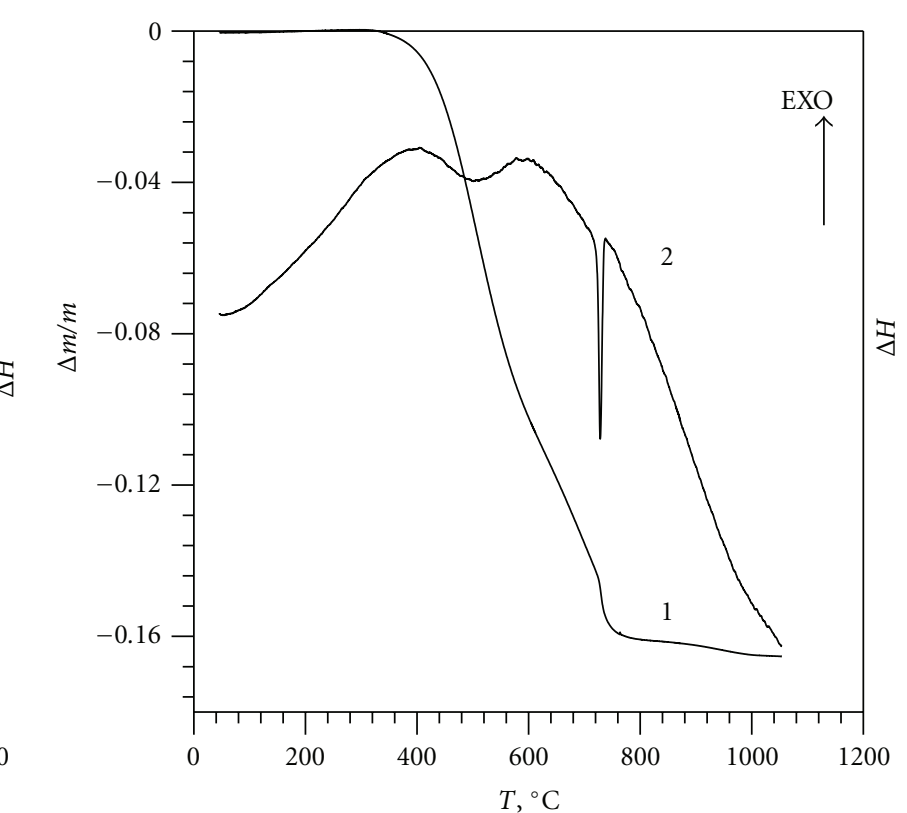

(b)

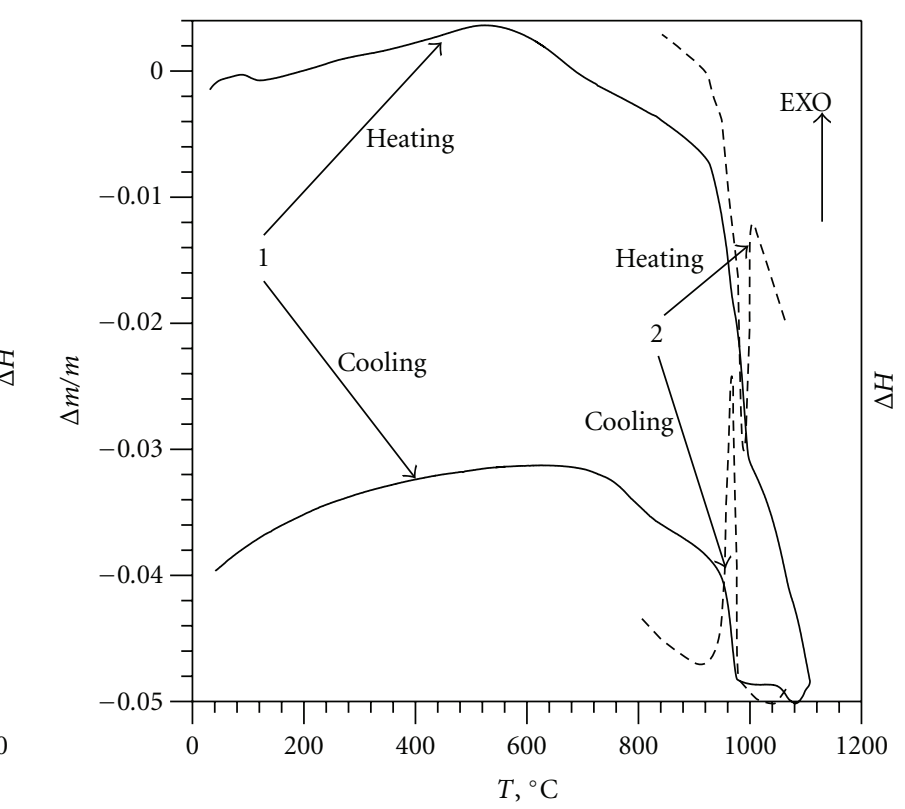

(d)

FIGURE 1: Thermal analysis of cobaltites formation (heating rate $5^{\circ} \mathrm{C} / \mathrm{min}$, in air). (a) Formation of the $\gamma-\mathrm{Na}_{x} \mathrm{CoO}_{2}$ from a mixture of $\mathrm{Co}_{3} \mathrm{O}_{4}$ and $\mathrm{Na}_{2} \mathrm{CO}_{3}$ : 1-TG, 2-DTG, 3-DTA. Dotted lines-adsorbed water removal; (b) formation of the $\mathrm{LiCoO}_{2}$ from a mixture of $\mathrm{Co}_{3} \mathrm{O}_{4}$ and $\mathrm{Li}_{2} \mathrm{CO}_{3}$ : 1-TG, 2-DTA; (c) formation of the mixed lithium-sodium cobaltite " $\mathrm{Li}_{0.5} \mathrm{Na}_{0.5} \mathrm{CoO}_{2}$ " by the reaction (6): 1-TG, 2-DTG, 3-DTA; (d) formation of the mixed lithium-sodium cobaltite " $\mathrm{Li}_{0.5} \mathrm{Na}_{0.5} \mathrm{CoO}_{2}$ " from a mixture of $\mathrm{LiCoO}_{2}$ and $\gamma-\mathrm{Na}_{0.7} \mathrm{CoO}_{2}$ : 1-TG, 2-DTA.

3.1.2. Formation of $\mathrm{LiCoO}_{2}$ from a Mixture of $\mathrm{Co}_{3} \mathrm{O}_{4}$ and $\mathrm{Li}_{2} \mathrm{CO}_{3}$. The TG-DTA curves of a mixture of the $\mathrm{Co}_{3} \mathrm{O}_{4}$ oxide and the lithium carbonate $\mathrm{Li}_{2} \mathrm{CO}_{3}$ taken in the ratio necessary for the obtaining of the hexagonal cobaltite $\mathrm{LiCoO}_{2}$ are shown in Figure 1(b). In comparison with $\mathrm{Na}_{0.7} \mathrm{CoO}_{2}$, the lithium cobaltite $\mathrm{LiCoO}_{2}$ is a more stable phase, and there are no effects on the curves associated with melting or evaporation. Decomposition of $\mathrm{Co}_{3} \mathrm{O}_{4}$ via reaction (3) does not occur either, since the formation of $\mathrm{LiCoO}_{2}$ proceeds with a greater speed and terminates to $900^{\circ} \mathrm{C}$, when this reaction is possible.

Weight losses are revealed beginning with the temperature $400^{\circ} \mathrm{C}$. Initially, they are caused probably by the decomposition of the lithium carbonate:

$$
\mathrm{Li}_{2} \mathrm{CO}_{3} \longrightarrow \mathrm{Li}_{2} \mathrm{O}+\mathrm{CO}_{2} \uparrow
$$




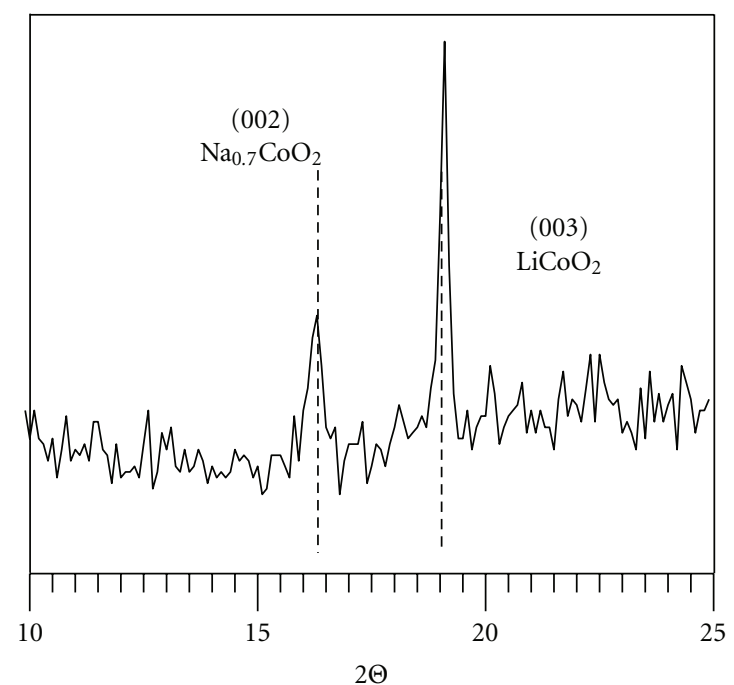

(a)

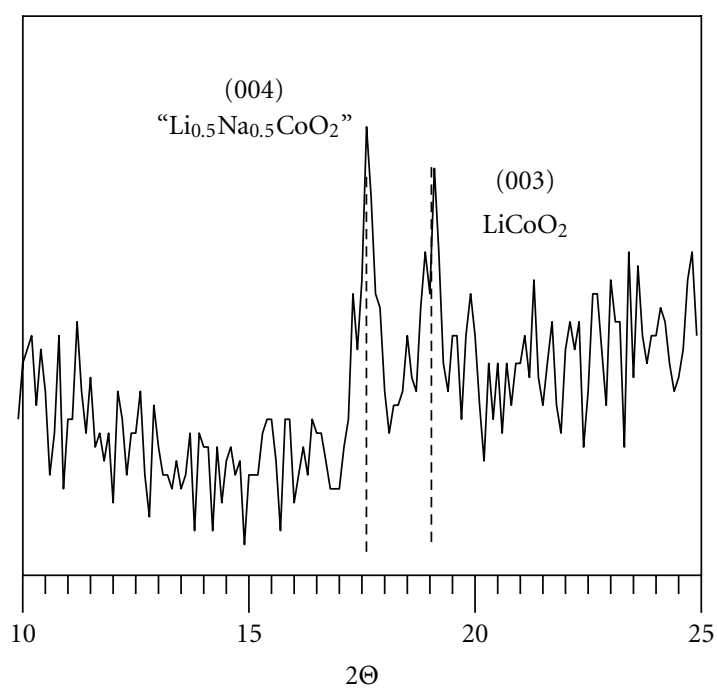

(b)

FIGURE 2: Fragments of powder diffraction patterns of the annealed and quenched mixture of carbonates and $\mathrm{Co}_{3} \mathrm{O}_{4}$ taken in the ratio corresponding to reaction (6): (a) $T_{\text {annel }}=686^{\circ} \mathrm{C}$; (b) $T_{\text {annel }}=895^{\circ} \mathrm{C}$.

It should be noted that although $\mathrm{Li}_{2} \mathrm{CO}_{3}$ is stable in air to $750^{\circ} \mathrm{C}$ [36], in reaction mixtures with several oxides it can decompose at much lower temperatures $[37,38]$. This process is accompanied by a diffuse endothermic effect at about $500^{\circ} \mathrm{C}$.

At higher temperatures, mainly reactions of lithium cobaltite formation take place:

$$
\begin{gathered}
0.5 \mathrm{Li}_{2} \mathrm{CO}_{3}+\frac{1}{3} \mathrm{Co}_{3} \mathrm{O}_{4}+0.125 \mathrm{O}_{2} \longrightarrow \mathrm{LiCoO}_{2}+0.5 \mathrm{CO}_{2} \uparrow \\
0.5 \mathrm{Li}_{2} \mathrm{O}+\frac{1}{3} \mathrm{Co}_{3} \mathrm{O}_{4}+0.125 \mathrm{O}_{2} \longrightarrow \mathrm{LiCoO}_{2} .
\end{gathered}
$$

In this region, the TG curve becomes more flattened. The endothermic effect observed on the DTA curve at $723^{\circ} \mathrm{C}$ may be attributed to melting of the unreacted $\mathrm{Li}_{2} \mathrm{CO}_{3}$ residue. As is seen from Figure 1(b), the weight loss near the melting point becomes greater probably owing to an increased rate of reaction (5) with participation of the molten carbonate. Total losses are $\approx 16 \%$ of the initial weight, which corresponds to the theoretical value.

\subsubsection{Formation of the Mixed Lithium-Sodium Cobaltite} " $\mathrm{Li}_{0.5} \mathrm{Na}_{0.5} \mathrm{CoO}_{2}$ " from a Mixture of Carbonates and $\mathrm{Co}_{3} \mathrm{O}_{4}$. As follows from [28], the mixed layered cobaltite has the composition $\mathrm{Li}_{0.43} \mathrm{Na}_{0.36} \mathrm{CoO}_{1.96}$. The formation of this particular composition from a mixture of carbonates and the cobalt oxide is described as

$$
\begin{gathered}
0.215 \mathrm{Li}_{2} \mathrm{CO}_{3}+0.180 \mathrm{Na}_{2} \mathrm{CO}_{3}+0.333 \mathrm{Co}_{3} \mathrm{O}_{4}+0.117 \mathrm{O}_{2} \\
\longrightarrow \mathrm{Li}_{0.43} \mathrm{Na}_{0.36} \mathrm{CoO}_{1.96}+0.395 \mathrm{CO}_{2} \uparrow
\end{gathered}
$$

Figure 1(c) clearly shows that the process is of a twostage character. The first stage $\left(300-680^{\circ} \mathrm{C}\right)$ is similar to the lithium cobaltite formation (Figure 1(b)). However, the real weight loss at this stage is by about $13 \%$ higher than that in reaction (5). This evidently means that the sodium carbonate also participates in the first stage of the mixed cobaltite formation. To confirm parallel formation of lithium and sodium cobaltites at the first stage of the process, a mixture of carbonates and $\mathrm{Co}_{3} \mathrm{O}_{4}$ taken in the ratio corresponding to reaction (6) was annealed at $686^{\circ} \mathrm{C}$ independently of the thermogravimetric experiment and then quenched. Xray diffraction analysis of the quenched sample revealed the presence both of $\mathrm{LiCoO}_{2}$ and $\gamma-\mathrm{Na}_{0.7} \mathrm{CoO}_{2}$ phases (Figure 2(a)). In addition, small traces of $\mathrm{Co}_{3} \mathrm{O}_{4}$ were fixed (strong diffraction lines for $\mathrm{Co}_{3} \mathrm{O}_{4}$ are within a different angle interval and therefore were not present in the given pattern).

As it is seen from the thermogram (Figure 1(c)), the second stage of the ordered mixed cobaltite synthesis begins at the temperature $\approx 780^{\circ} \mathrm{C}$, which is significantly higher than that for the $\mathrm{Na}_{0.7} \mathrm{CoO}_{2}$ formation (Figure 1(c)). Therefore, it can be assumed that the second stage is described mainly by the following reaction:

$$
\begin{gathered}
0.430 \mathrm{LiCoO}_{2}+0.180 \mathrm{Na}_{2} \mathrm{CO}_{3}+0.223 \mathrm{Co}_{3} \mathrm{O}_{4}+0.014 \mathrm{O}_{2} \\
\longrightarrow \mathrm{Li}_{0.43} \mathrm{Na}_{0.36} \mathrm{CoO}_{1.96}+0.180 \mathrm{CO}_{2} \uparrow
\end{gathered}
$$

The formation of the mixed lithium-sodium cobaltite was confirmed by XRD data. Figure 2(b) demonstrates a part of the X-ray diffraction pattern of the annealed at $895^{\circ} \mathrm{C}$ and quenched mixture of carbonates and $\mathrm{Co}_{3} \mathrm{O}_{4}$ taken in the ratio corresponding to reaction (6). After quenching from $895^{\circ} \mathrm{C}$, the sample contained a significant amount of $\mathrm{LiCoO}_{2}$ in addition to the ordered cobaltite " $\mathrm{Li}_{0.5} \mathrm{Na}_{0.5} \mathrm{CoO}_{2}$."

The DTA curve (curve 3, Figure 1(c)) reveals a number of endothermic effects: the effects at $\approx 500^{\circ} \mathrm{C}$ and $\approx 837^{\circ} \mathrm{C}$ correspond to active decomposition of lithium and sodium carbonates, respectively, while the thermal effect at $866^{\circ} \mathrm{C}$ is 
associated with melting of residual undecomposed sodium carbonate. A weak endothermic effect at $930^{\circ} \mathrm{C}$ points to the formation of the mixed lithium-sodium cobaltite.

3.1.4. Formation of " $\mathrm{Li}_{0.5} \mathrm{Na}_{0.5} \mathrm{CoO}_{2}$ " from a Mixture of $\mathrm{LiCoO}_{2}$ and $\mathrm{Na}_{0.7} \mathrm{CoO}_{2}$. Numerous and therefore difficultto-control chemical processes occurring during synthesis of " $\mathrm{Li}_{0.5} \mathrm{Na}_{0.5} \mathrm{CoO}_{2}$ " from carbonates and $\mathrm{Co}_{3} \mathrm{O}_{4}$ complicate the obtaining of a single-phase product. So, it is reasonable to consider the thermal behavior of a mixture of $\mathrm{LiCoO}_{2}$ and $\gamma-\mathrm{Na}_{0.7} \mathrm{CoO}_{2}$ prepared in advance and taken in the ratio required to obtain $\mathrm{Li}_{0.43} \mathrm{Na}_{0.36} \mathrm{CoO}_{2}$. The mixture was heated both in air and in oxygen flow. According to $\mathrm{XRD}$, this process actually leads to the obtaining of the desired mixed cobaltite " $\mathrm{Li}_{0.5} \mathrm{Na}_{0.5} \mathrm{CoO}_{2}$." Figure $1(\mathrm{~d})$ shows the weight changes and the corresponding thermal effects accompanying the interaction between lithium and sodium cobaltites. The weight changes below $T \approx 1000^{\circ} \mathrm{C}$ are not accompanied by any thermal effects and according to [39] reflect the oxygen stoichiometry variation in $\gamma-\mathrm{Na}_{0.7} \mathrm{CoO}_{2 \pm z}$. The endothermic effect at $T \approx 1000^{\circ} \mathrm{C}$ (Figure $1(\mathrm{~d})$, curve 2) indicates that it is exactly at this temperature that the formation of the ordered phase becomes possible. The main feature of the ordering process is a significant weight loss (curve 1). As is evident from Figure 1(d), this weight loss is at least partly reversible and therefore can be associated only with oxygen liberation. During a relatively slow cooling under thermogravimetric experiment conditions, the ordered phase " $\mathrm{Li}_{0.5} \mathrm{Na}_{0.5} \mathrm{CoO}_{2}$ " decomposes, which is attested by the exothermic effect at $\approx 940^{\circ} \mathrm{C}$ and the weight increase. XRD measurements of a slowly cooled sample reveal the presence of significant amounts of $\mathrm{LiCoO}_{2}$ and $\gamma-\mathrm{Na}_{0.7} \mathrm{CoO}_{2}$. Therefore, in order to prepare a pure mixed cobaltite " $\mathrm{Li}_{0.5} \mathrm{Na}_{0.5} \mathrm{CoO}_{2}$," it is necessary to quench the sample from $T \sim 1000-1025^{\circ} \mathrm{C}$. Heating to higher temperatures turned out to result in an irreversible loss of sodium in the form of $\gamma-\mathrm{Na}_{0.7} \mathrm{CoO}_{2}$. The final weight decrease observed on the thermal curve (1-heating, Figure 1(d)) corresponds to this process. Crystals of the sodium cobaltite were found on the walls of the crucible (Figure 3, insert). In this case, the reaction product after cooling contains an admixture of lithium cobaltite. Sodium loss can be suppressed if annealing is carried out in oxygen flow. Figure 3 shows the diffraction patterns of samples obtained by annealing of $\mathrm{LiCoO}_{2}-\gamma-\mathrm{Na}_{0.7} \mathrm{CoO}_{2}$ mixtures in oxygen flow and in air. As is seen, the first pattern reflects only the target single-phase formation, whereas the second pattern contains diffraction lines inherent to the $\mathrm{LiCoO}_{2}$ impurity.

\subsection{Characterization of the Mixed Lithium-Sodium Cobaltite} " $\mathrm{Li}_{0.5} \mathrm{Na}_{0.5} \mathrm{CoO}_{2}$ ". Based on foregoing DTA-TG studies of the lithium-sodium cobaltite formation, we chose the following conditions for its synthesis. Stoichiometric amounts of $\mathrm{LiCoO}_{2}$ and $\gamma-\mathrm{Na}_{0.7} \mathrm{CoO}_{2}$ were mixed thoroughly in an agate mortar, pressed into a pellet, annealed at $1050^{\circ} \mathrm{C}$ for 6 hours in oxygen flow, and then quenched onto a thick copper plate. According to X-ray analysis, the obtained sample had a structure identical to that described in [28] and did not contain

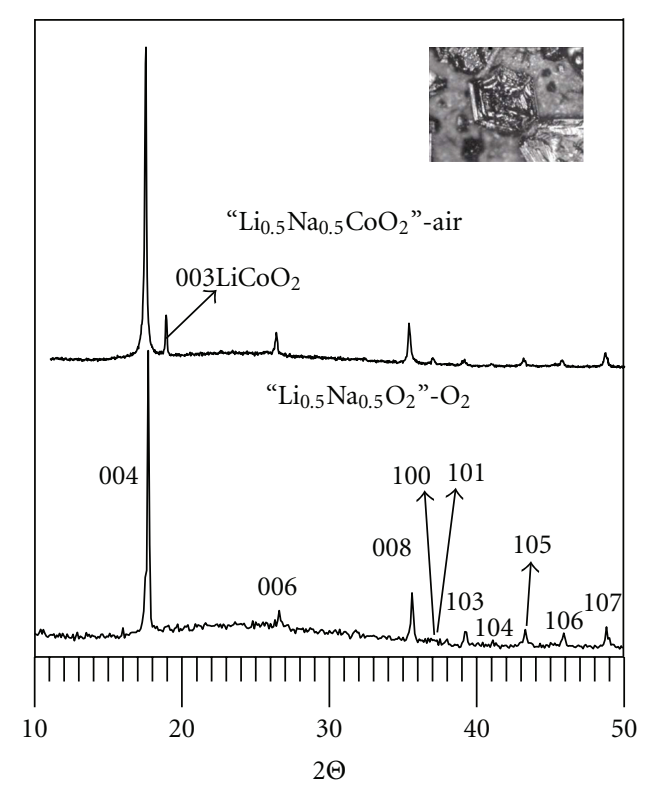

FIgURE 3: Powder diffraction patterns of samples obtained by annealing of $\mathrm{LiCoO}_{2}-\gamma-\mathrm{Na}_{0.7} \mathrm{CoO}_{2}$ mixtures at $T=1050^{\circ} \mathrm{C}$ in oxygen flow, and in air with following quenching. Insert: crystals of the sodium cobaltite found on the walls of the crucible after annealing of the mixture in air.

any impurities (Figure 3 ). The hexagonal cells parameters of " $\mathrm{Li}_{0.5} \mathrm{Na}_{0.5} \mathrm{CoO}_{2}$ " were $a=2.82(8) \AA$ and $c=20.32(3) \AA$. The contents of alkaline elements determined by ICP-AES analysis were found to be 2.86 and $8.10 \mathrm{wt} \%$ for $\mathrm{Li}$ and $\mathrm{Na}$, respectively. This allowed us to write the formula of the lithium-sodium mixed cobaltite as $\mathrm{Li}_{0.42} \mathrm{Na}_{0.36} \mathrm{CoO}_{2}$. According to TG data (Figure 1(d)), the weight loss during the synthesis of the mixed cobaltite was about $3 \mathrm{wt} \%$. This corresponds with the liberation of $\approx 10 \%$ of the initial oxygen, and hence the stoichiometric oxygen index in the mixed cobaltite close to the formation temperature is $\approx 1.8$. During decomposition of the $\mathrm{Li}-\mathrm{Na}$ phase into $\mathrm{LiCoO}_{2}$ and $\gamma-\mathrm{Na}_{0.7} \mathrm{CoO}_{2}$, the oxygen content increases (Figure $1(\mathrm{~d})$ ). So, the appearance of a rather great amount of oxygen defects may be considered as the necessary condition for the mixed lithium-sodium cobaltite formation. In order to estimate the oxygen content in the mixed $\mathrm{Li}-\mathrm{Na}$ cobaltite at room temperature, the weight of the single-phase sample obtained by annealing and following quenching of the lithium and sodium cobaltites mixture in oxygen flow was compared with that of the initial mixture. The measured weight loss turned out to be $1.18 \%$, which corresponds with the oxygen index 1.92 in the mixed cobaltite. Slow cooling under the same conditions does not lead to any weight changes.

Figure 4 displays the scanning electron microscopy (SEM) images illustrating the typical microstructure of the synthesized polycrystalline $\mathrm{Li}_{0.42} \mathrm{Na}_{0.36} \mathrm{CoO}_{2}$. The grain sizes range from 1 to $30 \mu \mathrm{m}$. The material clearly shows features of a layered structure. The crystal structure of this material is based on close packed layers of edge-sharing $\mathrm{CoO}_{2}$ octahedra, which are perpendicular to the $c$-axis and are separated by Na- or Li-containing sheets. The crystals can 


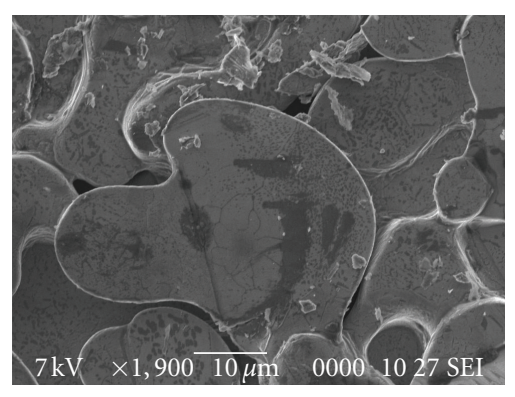

(a)

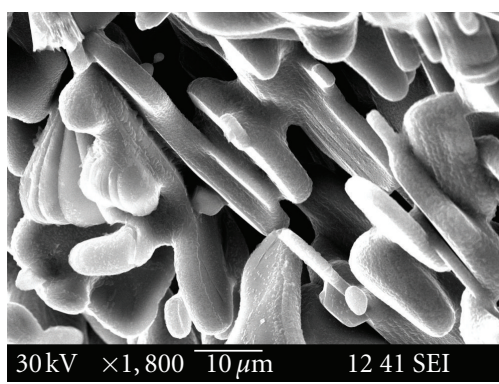

(b)

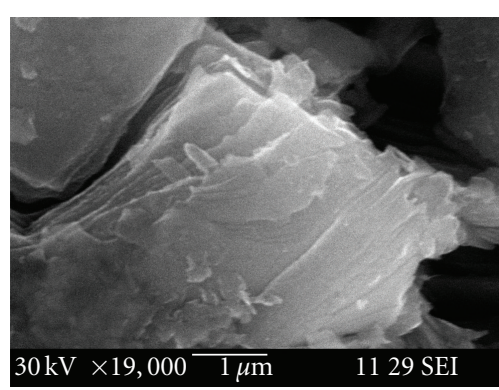

(c)

FIgURE 4: Scanning electron micrograph of the $\mathrm{Li}_{0.42} \mathrm{Na}_{0.36} \mathrm{CoO}_{2}$ : (a) frontal surface, (b) side surface, (c) chip.

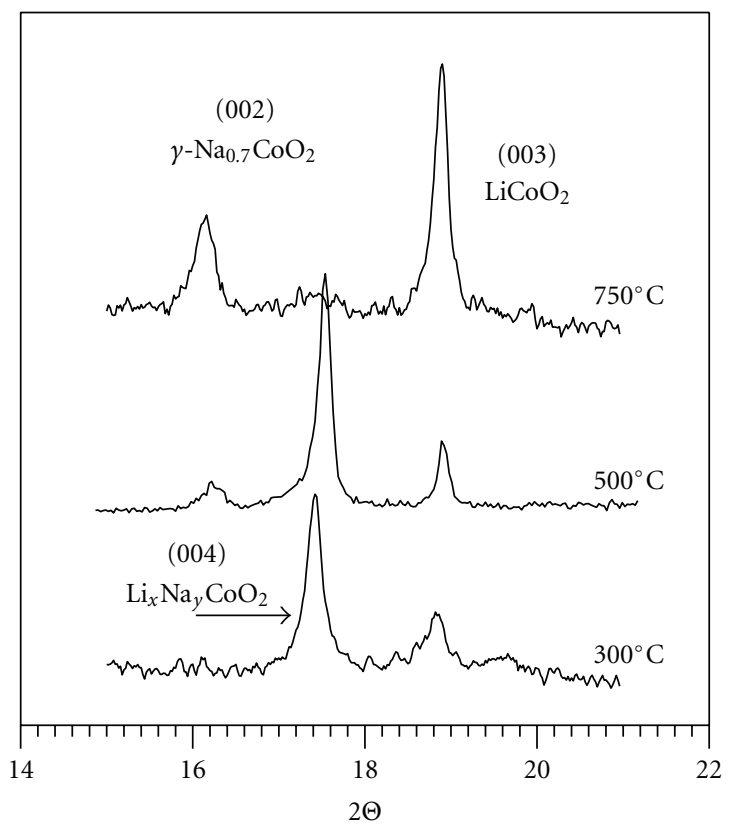

FIGURE 5: Fragments of powder diffraction patterns of the $\mathrm{Li}_{0.42} \mathrm{Na}_{0.36} \mathrm{CoO}_{2}$ heated to the different temperatures in the $\mathrm{O}_{2}$ flow.

be cleaved easily between the $\mathrm{CoO}_{2}$ layers and give rise to noticeable layered crystalline fragments, as displayed in the SEM images, especially in Figure 4(c). Another feature of the observed microstructure is a partly "fused" form of the grain surface (Figure 4(a)). It can be assumed that this is due to partial decomposition of the near-surface zone of the quenched $\mathrm{Li}_{0.42} \mathrm{Na}_{0.36} \mathrm{CoO}_{2}$ and to incongruent melting of the liberated sodium cobaltite [35].

The mixed lithium-sodium cobaltite was proved to be stable only at high temperatures and can therefore be obtained only by quenching. Heating of the quenched sample leads to its decomposition. An admixture of $\mathrm{LiCoO}_{2}$ is detected starting from $250^{\circ} \mathrm{C}$ and then at about $750^{\circ} \mathrm{C}$ $\mathrm{Li}_{0.42} \mathrm{Na}_{0.36} \mathrm{CoO}_{2}$ completely decomposes into mixture of $\mathrm{LiCoO}_{2}$ and $\gamma-\mathrm{Na}_{0.7} \mathrm{CoO}_{2}$ (Figure 5). Taking this into account, we assume that $\mathrm{Li}-\mathrm{Na}$ cobaltite can be considered as thermoelectric material only for low-temperature application. Both resistivity and thermopower of $\mathrm{Li}_{0.42} \mathrm{Na}_{0.36} \mathrm{CoO}_{2}$ measured at low temperatures are given in Figure 6. The

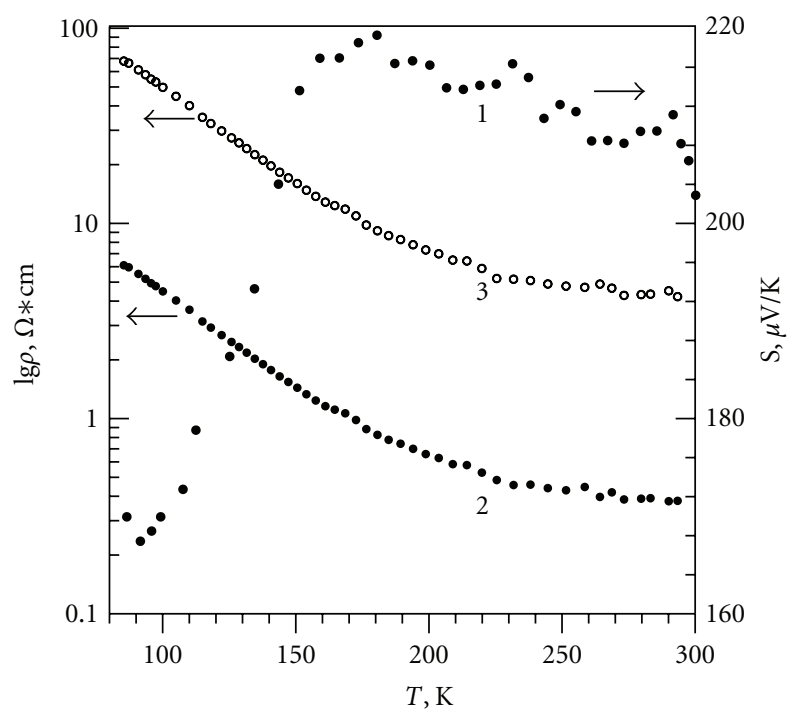

Figure 6: Temperature dependence of the thermopower $(S)$ and electrical resistivity $(\rho)$ for the $\mathrm{Li}_{0.42} \mathrm{Na}_{0.36} \mathrm{CoO}_{2}$ : curve 1thermopower; curve 2-electrical resistivity of the single-phase $\mathrm{Li}_{0.42} \mathrm{Na}_{0.36} \mathrm{CoO}_{2}$; curve 3-electrical resistivity of the partly decomposed $\mathrm{Li}_{0.42} \mathrm{Na}_{0.36} \mathrm{CoO}_{2}$ contained $3 \% \mathrm{LiCoO}_{2}$.

thermopower increases at first to a value $\approx 220 \mu \mathrm{V} / \mathrm{K}$ and then remains practically constant (curve 1). The existence of nonstoichiometry in the oxygen sublattice and a sublattice of an alkali metal in this compound may lead to the formation of ions as $\mathrm{Co}^{2+}$ and $\mathrm{Co}^{4+}$. The positive sign of Seebeck coefficient reflects the majority of hole-like contribution to charge transfer associated with $\mathrm{Co}^{4+}$. It is a common feature for other cobaltites [40, 41].

The resistivity of $\mathrm{Li}_{0.42} \mathrm{Na}_{0.36} \mathrm{CoO}_{2}$ exhibits the semiconductor behavior in this temperature range (curve 2). The room temperature resistivity is about $0.4 \mathrm{Ohm} * \mathrm{~cm}$. Detailed analysis of the transport properties is beyond the scope of this study, but it should be noted that obtained values are comparable to that of the other layered cobaltites considered as perspective thermoelectric materials. It is important that precipitation of only $3 \%$ of $\mathrm{LiCoO}_{2}$ leads to a sharp deterioration in the conductivity (curve 3). It seems to be due to the structural peculiarities of the $\mathrm{Li}_{0.42} \mathrm{Na}_{0.36} \mathrm{CoO}_{2}$ decomposition. 


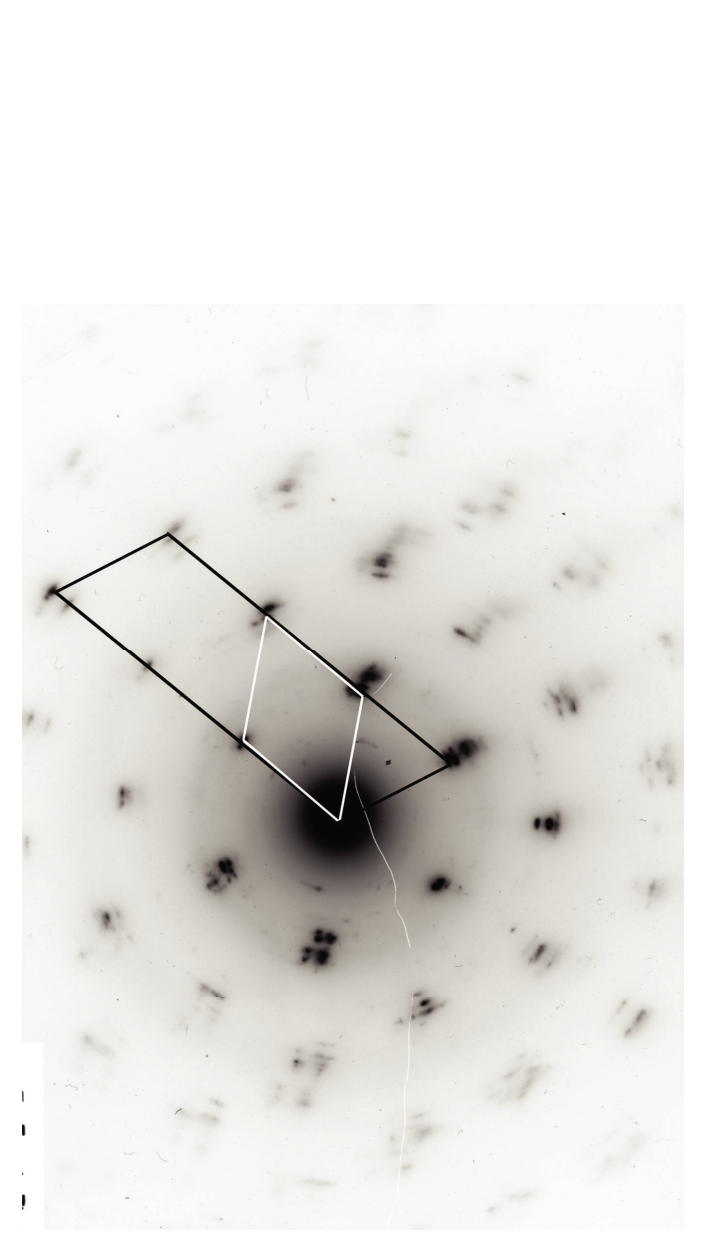

(a)

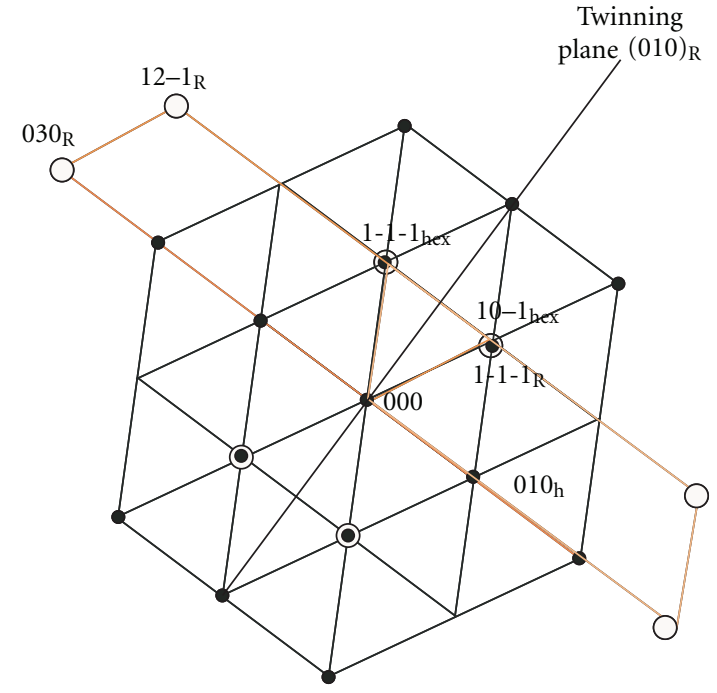

(b)

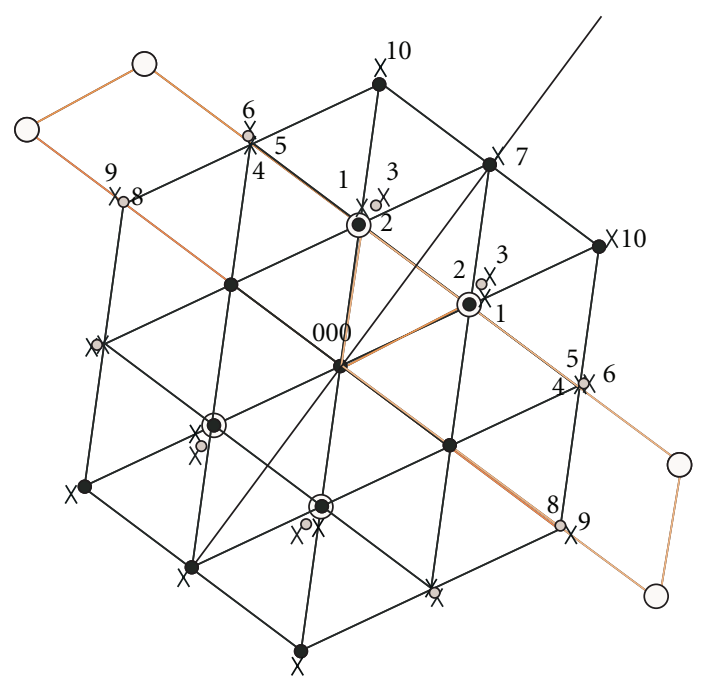

(c)

FIGURE 7: Electron diffraction pattern obtained from crystal aggregate of $\mathrm{Li}_{0.42} \mathrm{Na}_{0.36} \mathrm{CoO}_{2}$ subjected to ultrasonic dispersion (a) and its schemes (b, c). Black lines and white lines in (a) show nets of the $(101)^{*}$ cross-sections of $\mathrm{LiCoO}_{2}$ and $\gamma$ - $\mathrm{Na}_{0.7} \mathrm{CoO}_{2}$, respectively. Indexing of the reflections for $\mathrm{LiCoO}_{2}(\mathrm{R}), \gamma-\mathrm{Na}_{0.7} \mathrm{CoO}_{2}$ (hex) and $\mathrm{Li}_{0.42} \mathrm{Na}_{0.36} \mathrm{CoO}_{2}$ (hex') is shown: for (101)* cross-sections (b); for other Laue zones (c). Notations: bullet—reflections of $(101)^{*} \mathrm{NaCoO}_{2}$; white circle-reflections of $(101) * \mathrm{LiCoO}_{2}$; gray circle, cross (numbers from 1 to 10) - reflections of $\mathrm{NaCoO}_{2}$ and $\mathrm{LiCoO}_{2}$ that not belonging to (101)* cross-section (see Table 1).

\subsection{Electron Microscopic Study of $\mathrm{Li}_{0.42} \mathrm{Na}_{0.36} \mathrm{CoO}_{2}$ Decom-} position. In order to investigate the structural features of the long-period phase decomposition, we performed an electron microscopic study of $\mathrm{Li}_{0.42} \mathrm{Na}_{0.36} \mathrm{CoO}_{2}$, which was subjected to thermal treatment at $500^{\circ} \mathrm{C}$. According to X-ray analysis, upon thermal treatment the single-phase sample of $\mathrm{Li}_{0.42} \mathrm{Na}_{0.36} \mathrm{CoO}_{2}$ partially decomposed, and the diffraction pattern contained lines both of $\mathrm{LiCoO}_{2}$ and $\gamma-\mathrm{Na}_{0.7} \mathrm{CoO}_{2}$ in addition to the reflections of the main phase. Precipitation of $\mathrm{LiCoO}_{2}$ and $\gamma-\mathrm{Na}_{0.7} \mathrm{CoO}_{2}$ inevitably leads to a variation in the alkaline elements content in the mixed cobaltite. Taking in account this uncertainty, hereinafter we shall designate the mixed cobaltite as " $\mathrm{Li}_{x} \mathrm{Na}_{y} \mathrm{CoO}_{2}$."
A typical electron diffraction pattern obtained from 0.5$2 \mu \mathrm{m}$ anisotropic crystal aggregates of a mixed cobaltite sample is shown in Figure 7(a). Electron beam is perpendicular to mostly elongated planes of the aggregates. It contains not Debye rings but nets of point reflections, which may be indexed as individual cross-sections of the reciprocal lattice ( $\mathrm{rl}$ ) of the corresponding phases. The main feature of the diffraction pattern is the presence of several nets of reflexes with very close interplanar distances and close angles between the directions to the reflexes. As a rule, the angles are about $57-63^{\circ}$. These nets are close to the $(001)^{*}$ cross-sections of the reciprocal lattice associated with the hexagonal structure of the mixed lithium-sodium cobaltite. 
TABLe 1: Indexing of reflections for electron-diffraction pattern (Figure 7).

\begin{tabular}{|c|c|c|c|c|}
\hline$d \exp , \AA$ & Symbol & $d_{\text {hex }}, \AA\left(\gamma-\mathrm{NaCoO}_{2}, P 6_{3} / m m c\right)$ & $d_{R}, \AA\left(\mathrm{LiCoO}_{2}, R 3 m\right)$ & $d_{\text {hex' }}, \AA\left(\mathrm{Li}_{0.42} \mathrm{Na}_{0.36} \mathrm{CoO}_{2}, P 6_{3} / m c\right)$ \\
\hline \multicolumn{5}{|c|}{ The reflections of $(101) *$ cross-sections } \\
\hline 2.44 & - $\bigcirc$ & $2.46(010)$ & $2.43(010), \mathrm{I}=0$ & $2.46(010)$ \\
\hline \multirow[t]{2}{*}{2.43} & - $\bigcirc$ & $2.40(10-1)$ & $2.40(1-1-1)$ & $2.44(10-1)$ \\
\hline & & $2.40(1-1-1)$ & 2.40 (1-1-1), twin. reflect. & $2.44(1-1-1)$ \\
\hline 0.821 & 0 & $0.821(030)$ & $0.811(030)$ & $0.820(030)$ \\
\hline \multicolumn{5}{|c|}{ The reflections of adjacent Laue zone } \\
\hline \multirow{2}{*}{2.31} & \multirow{2}{*}{1} & & $2.299(10-2)$ & \multirow{2}{*}{$2.31(10-3)$} \\
\hline & & & 2.299 (10-2), twin. reflect. & \\
\hline 2.08 & 2 & $2.033(1-1-3)$ & & \\
\hline \multirow{2}{*}{1.97} & \multirow{2}{*}{3} & & $2.00(1-1-4)$ & \\
\hline & & & $2.00(1-1-4)$, twin. reflect. & \\
\hline \multirow[t]{2}{*}{1.41} & \multirow[t]{2}{*}{4} & & $1.405(1-20)$ & \multirow[t]{2}{*}{$1.416(1-20)$} \\
\hline & & & 1.405 (1-20), twin. reflect. & \\
\hline 1.368 & 5 & $1.375(1-2-2)$ & & $1.367(1-2-4)$ \\
\hline 1.348 & 6 & & $1.346(1-2-3)$ & \\
\hline 1.347 & 7 & & $1.346(2-1-3)$ & \\
\hline 1.215 & 8 & $1.220(022)$ & & \\
\hline 1.215 & 9 & & $1.212(021)$ & $1.210(02-3)$ \\
\hline 1.153 & 10 & & $1.150(-204)$ & \\
\hline
\end{tabular}

The series of close cross-sections shows first of all that in the studied textured aggregates there are individual crystallites, which are polar misoriented relative to the [001] direction. The mixed lithium-sodium cobaltite is characterized by a long-period structure in the " $c$ " direction, and therefore its diffraction pattern has dense rows of reflections directed along the $c^{*}$-axis of the reciprocal lattice. Another feature of the diffraction pattern obtained for the lithium-sodium cobaltite is that all the diffraction effects cannot be indexed within the $\mathrm{P}_{3} m c$ structure only.

The overwhelming majority of additional reflections can be indexed as a set of two phases- $-\mathrm{LiCoO}_{2}(R-3 \mathrm{~m}, a=$ $0.281 \mathrm{~nm}, c=1.405 \mathrm{~nm})$ and $\gamma-\mathrm{Na}_{0.7} \mathrm{CoO}_{2}\left(P 6_{3} / m m c, a=\right.$ $0.284 \mathrm{~nm}, c=1.081 \mathrm{~nm})$. Besides, $\mathrm{Na}_{0.75} \mathrm{CoO}_{2}(C 2 / m, a=$ $\left.0.490 \mathrm{~nm}, b=0.283 \mathrm{~nm}, c=0.572 \mathrm{~nm}, \beta=111.76^{\circ}\right)$ and lithium carbonate were also considered. Figure 6 shows a scheme of the $(101)^{*}$ cross-sections of the reciprocal lattices belonging to the mutually oriented $\gamma-\mathrm{Na}_{0.7} \mathrm{CoO}_{2}$ and $\mathrm{LiCoO}_{2}$ phases, which most closely coincide with the experimental reflections. The scheme is punched on the electron diffraction pattern too. Indexes of the reflections as well as interplanar spacing of the considered phases are given in Table 1. It should be noted that, in order to demonstrate indexing, we chose only one group of (101)* cross-sections, which is azimuthally misoriented relative to another group by several degrees.

In accordance with the performed calculations, $[010]^{*}$ as one of the basic directions of the reciprocal lattices coincides for $\mathrm{LiCoO}_{2}(R)$ and $\gamma-\mathrm{Na}_{0.7} \mathrm{CoO}_{2}$ (hex), while the [110]* and $[1-1-1]^{*}$ directions are misoriented within one degree. In addition to these reflections, the electron pattern contains a whole series of reflections that do not belong to the $(101)^{*}$ type cross-section of for these phases but are due to a deviation from the exact orientation of the $(101)^{*}$ plane or to elastic distortions in the lattice (Figures $7(\mathrm{~b})$ and $7(\mathrm{c})$ ). These are as a rule reflexes of the series directed along the $c^{*}$-axis and belonging to the $\mathrm{LiCoO}_{2}$ phase (marked with a cross in the diffraction pattern scheme in Figure $7(\mathrm{c})$ ). For example, in accordance with the extinction law, the $(10-1)_{R}$ reflections must be absent, but there are $(10-2)_{R}$ reflections from another zone, or, along with the $(1-1-1)_{R}$ reflections, observed are the reflections of the $(1-1-4)_{R}$ type belonging to another zone, the intermediate reflections $(1-1-2)_{R},(1-1-$ $3)_{R}$ being prohibited and having zero intensity (see Table 1). One more peculiarity of the diffraction pattern associated with $\mathrm{LiCoO}_{2}$ is the presence of two different orientations of the lattice with a twinning arrangement relative to each other.

Note that some of the reflections, which we indexed as $\mathrm{LiCoO}_{2}$ and $\gamma-\mathrm{Na}_{0.7} \mathrm{CoO}_{2}$, may belong also to $\mathrm{Li}_{0.42} \mathrm{Na}_{0.36} \mathrm{CoO}_{2}$. The lattice orientation of this phase is also close to the $(101)^{*}$ cross section (see Table 1 ). As is seen from this Table, the appearance of reflections from adjacent Laue zones is a characteristic feature of the diffraction pattern of the mixed lithium-sodium cobaltite. The same analysis can be performed for the second group of $(101)^{*}$ nets azimuthally misoriented relative to that described above. These two groups of reflections found in the crystalline aggregates seem to be associated with two blocks of $\mathrm{Li}_{0.42} \mathrm{Na}_{0.36} \mathrm{CoO}_{2}$ separated by a small-angle grain boundary.

A characteristic feature of individual diffraction spots on the electron diffraction pattern is not only the abovementioned polar blurring but also the azimuthal blurring also associated with the presence of misoriented crystallites in the aggregates. As follows from the dark-field TEM 


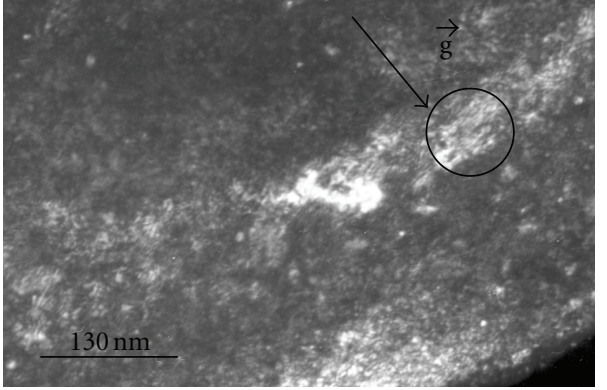

FIGURE 8: Dark-field TEM image in the reflections (1-1-1) hex , (1-1$1)_{\text {hex }^{\prime \prime}}$, and $(10-2)_{R}$ for crystal aggregate containing crystallites of the mutually oriented $\gamma-\mathrm{Na}_{0.7} \mathrm{CoO}_{2}, \mathrm{LiCoO}_{2}$, and " $\mathrm{Li}_{x} \mathrm{Na}_{y} \mathrm{CoO}_{2}$ " phases. Vector $\vec{g}$ of reflections for dark-field TEM image and area with fringe moiré contrast (white circle) are shown.

images obtained in the group of reflections (1-1-1) $\mathrm{Na}_{0.7} \mathrm{CoO}_{2}$,

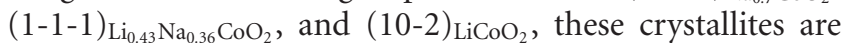
rather small (Figure 8 ). The size of the crystallites can be estimated from moiré contrast observed on the electron microscopic images. Both parallel moiré contrast (moiré fringes are perpendicular to the $\vec{g}$ vectors of the reflections for the dark-field image) and mixed moiré (fringes are inclined to the $\vec{g}$ vectors) are observed in the extinction contour (Figure 8). The former is due to the crystallites with different interplane distances, while the latter is produced by azimuthally misoriented regions also having different values of interplanar distances. The sizes of individual crystallites correspond to the sizes of domains with the same periodicity and direction of moiré fringes and are as small as 20$70 \mathrm{~nm}$.

Thus, the electron microscopic studies showed that in the crystal aggregates formed as a result of partial decomposition of the mixed cobaltite $\mathrm{Li}_{0.42} \mathrm{Na}_{0.36} \mathrm{CoO}_{2}$ the initial phase (hex') coexists with $\mathrm{LiCoO}_{2}(R)$ and $\gamma-\mathrm{Na}_{0.7} \mathrm{CoO}_{2}$ (hex). It is essential that the lattices of the initial phase and of the phases formed upon decomposition demonstrate mutual orientation. The orientation relations can be written as

$$
\begin{aligned}
& \text { (001)hex' }\|(001) R\|(001) \operatorname{hex}(7), \\
& \text { [100]hex' }\|[100] R\|[100] \operatorname{hex}(8) .
\end{aligned}
$$

In other words, close packed hexagonal planes and close packed directions of these planes coincide for the three coexisting phases. Significant parts of the cells have an identical type and sequence of the atomic layers. This can be seen from Figure 9 where the structures of the three phases with the selected common fragments are shown. Note that the observed features of the ordered mixed lithiumsodium cobaltite decomposition come from its "nanoblock" structure built up from weakly coupled $\gamma-\mathrm{Na}_{0.7} \mathrm{CoO}_{2}$ and $\mathrm{LiCoO}_{2}$ blocks [33].

We assume that the decomposition of $\mathrm{Li}_{0.42} \mathrm{Na}_{0.36} \mathrm{CoO}_{2}$ begins with the precipitation of $\mathrm{LiCoO}_{2}$ on the base of the corresponding fragment of the mixed cobaltite. This supposition is proved by the fact that according to X-ray data only the $\mathrm{LiCoO}_{2}$ impurity is observed at the initial stages of

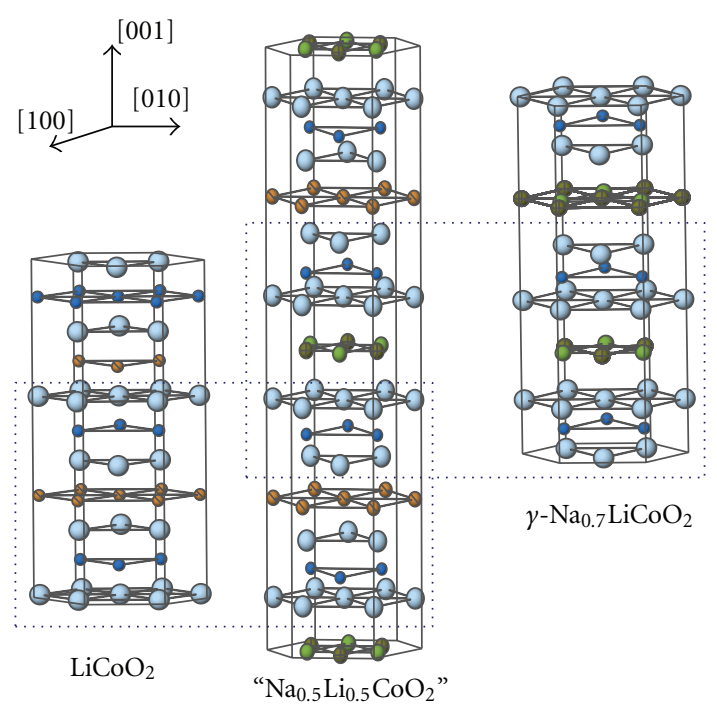

Figure 9: Crystal structures of the $\mathrm{LiCoO}_{2}$, " $\mathrm{Li}_{0.5} \mathrm{Na}_{0.5} \mathrm{CoO}_{2}$," and $\gamma-\mathrm{Na}_{0.7} \mathrm{CoO}_{2}$.

thermal decomposition of $\mathrm{Li}_{0.42} \mathrm{Na}_{0.36} \mathrm{CoO}_{2}$. The formation of $\mathrm{LiCoO}_{2}$ requires redistribution of $\mathrm{Li}$ and $\mathrm{Na}$ ions in one half of appropriate layers of the initial structure, the positions of the layers along the $c$-axis ([001] direction) in $\mathrm{LiCoO}_{2}$ and $\mathrm{Li}_{0.42} \mathrm{Na}_{0.36} \mathrm{CoO}_{2}$ being very close to each other. As to the rest of lithium, cobalt, and oxygen ions, they remain in the same layers and will shift by distances close to interatomic ones in the case of $\mathrm{LiCoO}_{2}$ formation. The sodium cobaltite $\gamma$ $\mathrm{Na}_{0.7} \mathrm{CoO}_{2}$ forms on the basis of the remaining fragment of the initial structure. A required redistribution of $\mathrm{Li}$ and $\mathrm{Na}$ ions can be achieved via their diffusion mainly in the (001) planes. As a result of the mixed cobaltite decomposition to $\mathrm{LiCoO}_{2}$ and $\gamma-\mathrm{Na}_{0.7} \mathrm{CoO}_{2}$, the grains in the initial crystal aggregates decrease not only in the [001] direction but also within the layers. The fine grain structure of the partly decomposed mixed cobaltite is confirmed by the electron microscopic study.

\section{Conclusion}

Formation and decomposition of the ordered lithiumsodium cobaltite " $\mathrm{Li}_{0.5} \mathrm{Na}_{0.5} \mathrm{CoO}_{2}$ " were investigated. The ordered phase is stable in narrow temperature interval. It forms at $T=1000^{\circ} \mathrm{C}$ and partly decomposes at $T>$ $1050^{\circ} \mathrm{C}$ due to an irreversible loss of sodium in the form of $\gamma-\mathrm{Na}_{0.7} \mathrm{CoO}_{2}$. The main feature of the mixed cobaltite formation is a significant weight loss associated with oxygen liberation. The appearance of a rather great amount of oxygen defects is considered as the necessary condition for the " $\mathrm{Li}_{0.5} \mathrm{Na}_{0.5} \mathrm{CoO}_{2}$ " formation.

In order to investigate the structural features of the phase decomposition, an electron microscopic study was performed. It was shown that the lattices of the initial phase and of the $\mathrm{LiCoO}_{2}$ and $\gamma-\mathrm{Na}_{0.7} \mathrm{CoO}_{2}$ formed upon decomposition demonstrate mutual orientation: close packed hexagonal planes and close packed directions of these planes coincide for the three coexisting phases. 


\section{Acknowledgment}

The authors would like to acknowledge the financial support from the Russian Foundation for Basic Research (Grant no. 10-03-00203-a, Grant no. 11-02-00166-a) and Programm no. 12-M-23-2032.

\section{References}

[1] S. Megahed and W. Ebner, "Lithium-ion battery for electronic applications," Journal of Power Sources, vol. 54, no. 1, pp. 155$162,1995$.

[2] C. Delmas, "Industrial chemistry library," in Lithium Batteries. New Materials, Developments and Perspectives, G. Pistoia, Ed., vol. 5, p. 457, Elsevier, New York, NY, USA, 1994.

[3] M. Ménétrier, I. Saadoune, S. Levasseur, and C. Delmas, "The insulator-metal transition upon lithium deintercalation from $\mathrm{LiCoO}_{2}$ : electronic properties and 7Li NMR study," Journal of Materials Chemistry, vol. 9, no. 5, pp. 1135-1140, 1999.

[4] J. Molenda, A. Stokłosa, and T. Bak, "Modification in the electronic structure of cobalt bronze $\mathrm{Li}_{x} \mathrm{CoO}_{2}$ and the resulting electrochemical properties," Solid State Ionics, vol. 36, no. 1-2, pp. 53-58, 1989.

[5] D. G. Kellerman, V. R. Galakhov, A. S. Semenova, Y. N. Blinovskov, and O. N. Leonidova, "Semiconductor-metal transition in defect lithium cobaltite," Physics of the Solid State, vol. 48, no. 3, pp. 548-556, 2006.

[6] S. Levasseur, M. Ménétrier, E. Suard, and C. Delmas, "Evidence for structural defects in non-stoichiometric HT$\mathrm{LiCoO}_{2}$ : electrochemical, electronic properties and 7Li NMR studies," Solid State Ionics, vol. 128, no. 1-4, pp. 11-24, 2000.

[7] P. W. Anderson, "Absence of diffusion in certain random lattices," Physical Review, vol. 109, no. 5, pp. 1492-1505, 1958.

[8] J. Sugiyama, H. Nozaki, J. H. Brewer, E. J. Ansaldo, G. D. Morris, and C. Delmas, "Frustrated magnetism in the twodimensional triangular lattice of $\mathrm{Li}_{x} \mathrm{CoO}_{2}$, " Physical Review B, vol. 72, no. 14, Article ID 144424, pp. 1-9, 2005.

[9] K. Mukai, Y. Ikedo, H. Nozaki et al., "Magnetic phase diagram of layered cobalt dioxide $\mathrm{Li}_{x} \mathrm{CoO}_{2}$," Physical Review Letters, vol. 99, no. 8, Article ID 087601, 2007.

[10] W. D. Johnston, R. R. Heikes, and D. Sestrich, "The preparation, crystallography, and magnetic properties of the $\mathrm{Li}_{x} \mathrm{Co}_{(1-x)} \mathrm{O}$ system," Journal of Physics and Chemistry of Solids, vol. 7, no. 1, pp. 1-13, 1958.

[11] J. N. Reimers and J. R. Dahn, "Electrochemical and in situ Xray diffraction studies of lithium intercalation in $\mathrm{Li}_{x} \mathrm{CoO}_{2}$," Journal of the Electrochemical Society, vol. 139, no. 8, pp. 20912097, 1992.

[12] C. Fouassier, G. Matejka, J. M. Reau, and P. Hagenmuller, "Sur de nouveaux bronzes oxygénés de formule $\mathrm{Na}_{\chi} \mathrm{CoO}_{2}(\chi 1)$. Le système cobalt-oxygène-sodium," Journal of Solid State Chemistry, vol. 6, no. 4, pp. 532-537, 1973.

[13] L. Viciu, J. W.G. Bos, H. W. Zandbergen et al., "Crystal structure and elementary properties of $\mathrm{Na}_{x} \mathrm{CoO}_{2}(x=0.32$, $0.51,0.6,0.75$, and 0.92 ) in the three-layer $\mathrm{NaCoO}_{2}$ family," Physical Review B, vol. 73, no. 17, Article ID 174104, 2006.

[14] Q. Huang, M. L. Foo, R. A. Pascal Jr. et al., "Coupling between electronic and structural degrees of freedom in the triangular lattice conductor $\mathrm{Na}_{x} \mathrm{CoO}_{2}$," Physical Review B, vol. 70, no. 18, Article ID 184110, pp. 1-7, 2004.

[15] Y. Takahashi, Y. Gotoh, and J. Akimoto, "Single-crystal growth, crystal and electronic structure of $\mathrm{NaCoO}_{2}$," Journal of Solid State Chemistry, vol. 172, no. 1, pp. 22-26, 2003.
[16] K. Takada, H. Sakurai, E. Takayama-Muromachi, F. Izumi, R. A. Dilanian, and T. Sasaki, "Superconductivity in twodimensional $\mathrm{CoO}_{2}$ layers," Nature, vol. 422, no. 6927, pp. 53$55,2003$.

[17] J. Sugiyama, J. H. Brewer, E. J. Ansaldo et al., "Dome-shaped magnetic phase diagram of thermoelectric layered cobaltites," Physical Review Letters, vol. 92, no. 1, Article ID 17602, pp. 14, 2004.

[18] J. L. Luo, N. L. Wang, G. T. Liu et al., "Metamagnetic transition in $\mathrm{Na}_{0.85} \mathrm{CoO}_{2}$ single crystals," Physical Review Letters, vol. 93, no. 18, Article ID 187203, 2004.

[19] S. P. Bayrakci, I. Mirabeau, P. Bourges et al., "Magnetic ordering and spin waves in $\mathrm{Na}_{0.82} \mathrm{CoO}_{2}$," Physical Review Letters, vol. 94, no. 15, Article ID 157205, 2005.

[20] R. Ray, A. Ghoshray, K. Ghoshray, and S. Nakamura, "59Co NMR studies of metallic $\mathrm{NaCO}_{2} \mathrm{O}_{4}$," Physical Review B, vol. 59, no. 14, pp. 9454-9461, 1999.

[21] P. Carretta, M. Mariani, C. B. Azzoni et al., "Mesoscopic phase separation in $\mathrm{Na}_{x} \mathrm{CoO}_{2}(0.65 \leq x \leq 0.75)$," Physical Review $B$, vol. 70, no. 2, Article ID 024409, 2004.

[22] M. G. S. R. Thomas, P. G. Bruce, and J. B. Goodenough, "Lithium mobility in the layered oxide $\mathrm{Li}_{1-x} \mathrm{CoO}_{2}$," Solid State Ionics, vol. 17, no. 1, pp. 13-19, 1985.

[23] I. Terasaki, Y. Sasago, and K. Uchinokura, "Large thermoelectric power in $\mathrm{NaCO}_{2} \mathrm{O}_{4}$ single crystals," Physical Review B, vol. 56, no. 20, pp. R12685-R12687, 1997.

[24] P. Liu, G. Chen, Y. Cui et al., "High temperature electrical conductivity and thermoelectric power of $\mathrm{Na}_{x} \mathrm{CoO}_{2}$," Solid State Ionics, vol. 179, no. 39, pp. 2308-2312, 2008.

[25] G. Peleckis, T. Motohashi, M. Karppinen, and H. Yamauchi, "Enhanced thermoelectric properties of $\mathrm{Na}_{x} \mathrm{CoO}_{2}$ whisker crystals," Applied Physics Letters, vol. 83, no. 26, pp. 5416-5418, 2003.

[26] Y. Ono, R. Ishikawa, Y. Miyazaki, Y. Ishii, Y. Morii, and T. Kajitani, "Crystal structure, electric and magnetic properties of layered cobaltite $\beta-\mathrm{Na}_{x} \mathrm{CoO}_{2}$," Journal of Solid State Chemistry, vol. 166, no. 1, pp. 177-181, 2002.

[27] A. S. Semenova, D. G. Kellerman, and A. A. Markov, "Electrical and magnetic properties of the $\mathrm{Li}_{0.42} \mathrm{Na}_{0.36} \mathrm{CoO}_{2}$," ECS Transactions, vol. 25, no. 33, pp. 155-162, 2010.

[28] R. J. Balsys and R. Lindsay Davis, "The structure of $\mathrm{Li}_{0.43} \mathrm{Na}_{0.36} \mathrm{CoO}_{1.96}$ using neutron powder diffraction," Solid State Ionics, vol. 69, no. 1, pp. 69-74, 1994.

[29] Z. Ren, J. Shen, S. Jiang et al., "Enhanced thermopower in an intergrowth cobalt oxide $\mathrm{Li}_{0.48} \mathrm{Na}_{0.35} \mathrm{CoO}_{2}$," Journal of Physics Condensed Matter, vol. 18, no. 29, pp. L379-L384, 2006.

[30] J. W. G. Bos, J. T. Hertz, E. Morosan, and R. J. Cava, "Magnetic and thermoelectric properties of layered $\mathrm{Li}_{x} \mathrm{Na}_{y} \mathrm{CoO}_{2}$," Journal of Solid State Chemistry, vol. 180, no. 11, pp. 3211-3217, 2007.

[31] X. Y. Chen, X. F. Xu, R. X. Hu, Z. Ren, Z. A. Xu, and G. H. Cao, "Synthesis and thermopower measurement of $\mathrm{Li}_{x} \mathrm{NayCoO}_{2}$," Wuli Xuebao/Acta Physica Sinica, vol. 56, no. 3, pp. 1627-1631, 2007.

[32] V. V. Mesilov, V. R. Galakhov, A. S. Semenova, D. G. Kellerman, and L. V. Elokhina, "X-ray spectra and specific features of the structure of lithium-sodium cobaltite $\mathrm{Li}_{x} \mathrm{Na}_{y} \mathrm{CoO}_{2}$," Physics of the Solid State, vol. 53, pp. 254-258, 2011.

[33] A. Semenova, D. Kellerman, I. Baklanova, L. Perelyaeva, and E. Vovkotrub, "Raman spectroscopy study of sodium-lithium cobaltite," Chemical Physics Letters, vol. 491, no. 4-6, pp. 169171, 2010.

[34] V. R. Galakhov, V. V. Karelina, D. G. Kellerman, V. S. Gorshkov, N. A. Ovechkina, and M. Neumann, "Electronic structure, $\mathrm{x}$-ray spectra, and magnetic properties of the $\mathrm{LiCoO}_{2}-\delta$ and 
$\mathrm{Na}_{x} \mathrm{CoO}_{2}$ nonstoichiometric oxides," Physics of the Solid State, vol. 44, no. 2, pp. 266-273, 2002.

[35] D. P. Chen, H. C. Chen, A. Maljuk et al., "Single-crystal growth and investigation of $\mathrm{Na}_{x} \mathrm{CoO}_{2}$ and $\mathrm{Na}_{x} \mathrm{CoO}_{2} \cdot y \mathrm{H}_{2} \mathrm{O}$," Physical Review B, vol. 70, no. 2, Article ID 024506, p. 1, 2004.

[36] D. R. Lide, Ed., Handbook of Chemistry and Physics, The Chemical Rubber Company Press, Ohio, USA, 74th edition, 1993-1994.

[37] W. U. Malik, D. R. Gupta, I. Masood, and R. S. Gupta, "Kinetic study of thermal decomposition of calcium carbonate in the presence of $\mathrm{K}_{2} \mathrm{CO}_{3}$ and $\mathrm{BaCO}_{3}$," Journal of Materials Science Letters, vol. 4, no. 5, pp. 532-536, 1985.

[38] E. Antolini, "The way of $\mathrm{Li}_{x} \mathrm{Ni}_{1-x} \mathrm{O}$ solid solution formation from an Ni-Li2CO3 powder mixture," Journal of Materials Science Letters, vol. 12, no. 24, pp. 1947-1950, 1993.

[39] J. M. Paulsen and J. R. Dahn, "Studies of the layered manganese bronzes, $\mathrm{Na} 2 / 3[\mathrm{Mn} 1-\mathrm{xMx}] \mathrm{O} 2$ with $\mathrm{M}=\mathrm{Co}, \mathrm{Ni}$, $\mathrm{Li}$, and $\mathrm{Li} 2 / 3[\mathrm{Mn} 1-\mathrm{xMx}] \mathrm{O} 2$ prepared by ion-exchange," Solid State Ionics, vol. 126, no. 1, pp. 3-24, 1999.

[40] P. Liu, G. Chen, Y. Cui et al., "High temperature electrical conductivity and thermoelectric power of $\mathrm{Na}_{x} \mathrm{CoO}_{2}$," Solid State Ionics, vol. 179, no. 39, pp. 2308-2312, 2008.

[41] S. Y. Istomin, E. V. Antipov, G. Svensson et al., "A novel complex cobalt gallium oxide $\mathrm{Ca}_{2} \mathrm{Co}_{0.8} \mathrm{Ga}_{1.2} \mathrm{O}_{4.8}$ : synthesis and high-temperature electron transport properties," Journal of Solid State Chemistry, vol. 167, no. 1, pp. 196-202, 2002. 


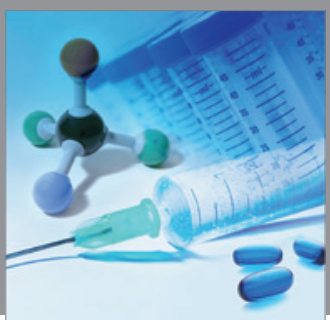

International Journal of

Medicinal Chemistry

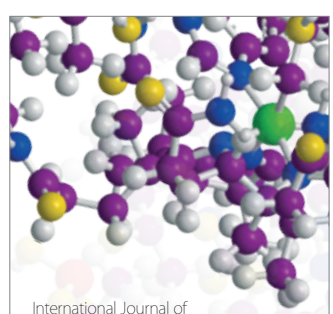

Carbohydrate Chemistry

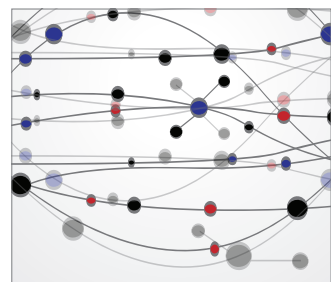

The Scientific World Journal
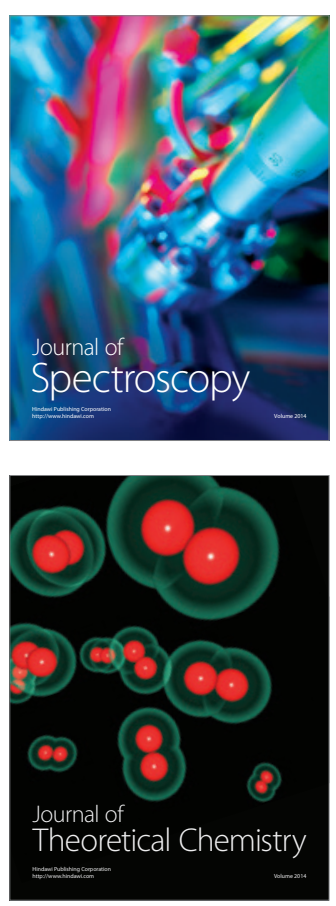
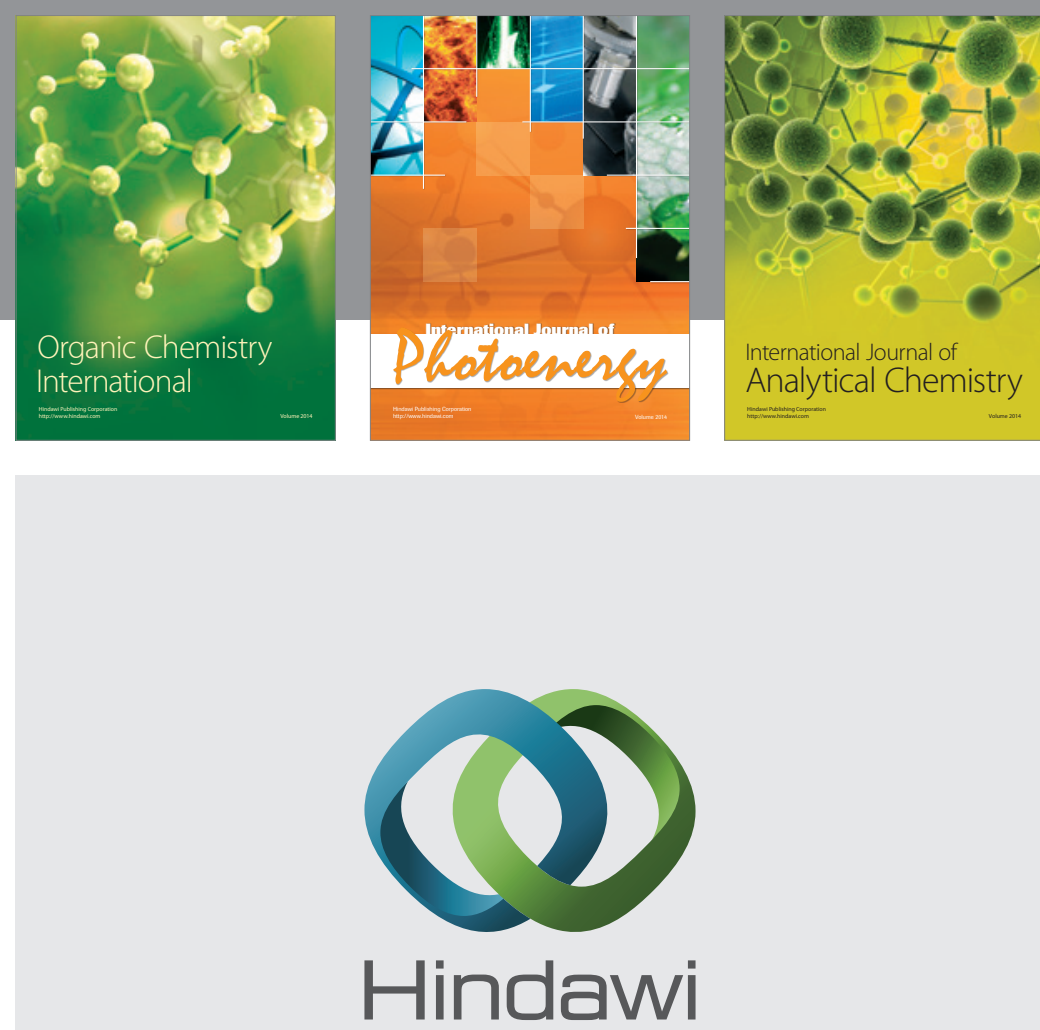

Submit your manuscripts at

http://www.hindawi.com
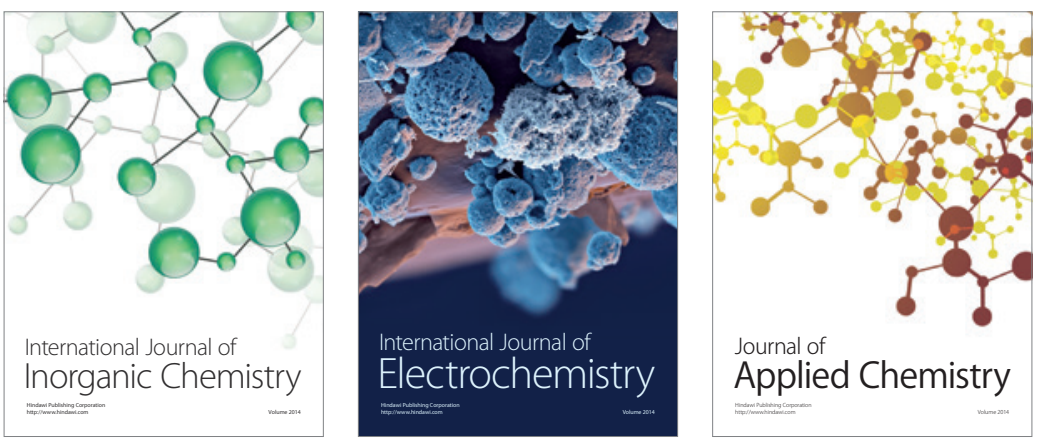

Journal of

Applied Chemistry
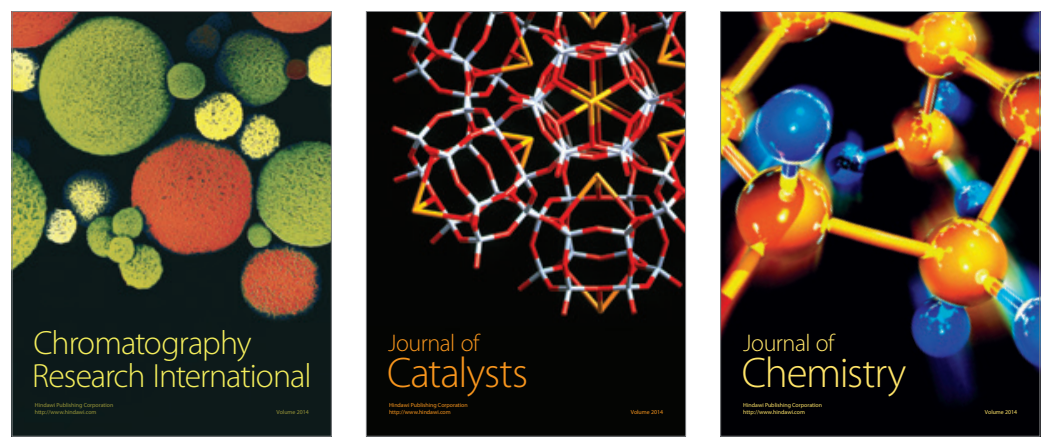
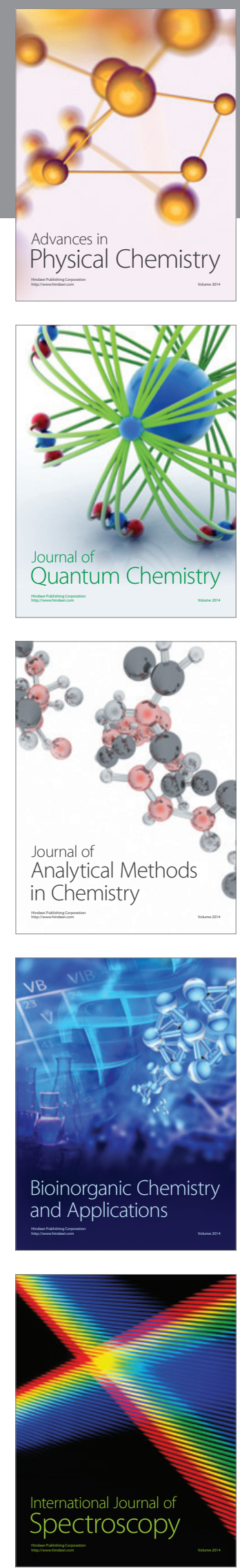